\title{
1945 - VOORTSETTING OF WEERKEER? - 1975
}

\author{
Dr. L. A. F. Godschalk \\ „Ek in hulle en $U$ in $M y$, sodat hulle \\ volkome een kant wees" (Joh. $17: 23 a$ ).
}

\section{Verantwoording}

Afskeiding of Vrymaking of watter ander daad van kerklike afskeid mag op grond van Jesus se verhoorde gebed uit Johannes 17 nooit plaasvind as die gemeenskap waarvan afskeid geneem word self geen toonbeeld van kerklike skeurmaking is nie. Daarom mag daardie daad nie net as Afskeiding of Vrymaking getipeer word nie, maar moet dit aangevul word met die woorde „of weerkeer" want in en deur dié afskeid word weergekeer tot die eenheid, die sigbare eenheid van die liggaam van Christus.

Bogenoemde verklaar die feit, dat die kerklike reformasies in Nederland uit die vorige en hierdie eeu offisieel aangedui word deur "Acte van Afscheiding of Wederkeering” en „Acte van Vrymaking of Wederkeer" (acte is handeling). Die woordjie "of" het hier die funksie van "oftewel": in die Afscheiding, in die Vrymaking word weergekeer tot die deur God gebore eenheid.

Dit is nuttig vir dié Gereformeerdes in Suid-Afrika wat uit Holland geëmigreer het om dit in herinnering te roep. Want Afskeiding of Vrymaking sonder meer is skeurmaking. As bv. ,vrygemaaktes" "ge-re-formeerdes" genoemd wil word, moet hulle ook "weergekeerdes" wees.

Om die rede mag ek - my soveel moontlik ook aansluitende aan die gebruikte terminologie - 'n kort samevatting gee van dié gedeeltes uit die "Acte van Vrymaking of Wederkeer" wat meer spesifiek op dié weerkeer betrekking het:

a. bereidheid om saam te lewe met alle wat die Dordtse kerkordening aangeneem het of sal aanneem;

b. bereidheid om gemeenskap te onderhou met alle gelowiges waar die Seun van God hulle ook al vergader het of sal vergader in die congregatio - en sonder 'n nie-katolieke eiewilligheid op die grondslag staan of sal gaan staan van net die drie formuliere van enigheid;

c. bereidheid om saam te staan in die deur God gebode kerklike eenheid met die wat onder verwerping van skismatiek voor 1942 die eenheid bewaar en vasgehou het;

d. bereidheid tot kerkvergaderende werk - in die coetus - sonder enige ander maatstaf as net die formuliere van enigheid en die Dordtse kerkeordening.

Dat ek hierdie voorbeeld kies en nie die van die Afskeiding nie, vind sy rede in die begrensing van „Voortsetting of Weerkeer" deur die jaartalle: 1945 en 1975. 
1945: Na vyf oorlogsjare kry Suid-Afrika weer kerklike kontak met Nederland.

1975: Die Geref. Kerk in S.A. berei hom voor op die sinode 1976 D.V., wat 'n finale besluit sal neem oor sy verhouding tot die sg. "Gereformeerde Kerken in Nederland".

Belangstelling in die jongste kerklike reformasie uit die tyd van onmoontlikheid van kontakoefening is dan wel baie nuttig, so nie gebode nie.

Die leser mag van my ewewel nie verwag dat ek in hierdie artikel 'n geskiedbeskrywing van die sg. Vrymaking gee nie. Ek wil slegs 'n klippie bydra vir die wegneming van die misgissing, asof dié kerke waarmee die Gereformeerde Kerken in Nederland (vrygemaak) in Suid-Afrika korrespondensie oefen, te wete die Vrye Geref. Kerke te Pretoria en te Kaapstad, 'n getrouwe „monster" bied van wat hulle Ned. susterkerke bely en belewe. Sombere uitlatings oor die vooruitsigte van korrespondensie met die vrygemaakte kerke in Nederland word ten onregte onder sekere Gereformeerdes gewek deur te wys na die repeterende breuke in die Vrye Geref. Kerke te Pretoria en Kaapstad vanaf 1950 tot nou. Ek sou dieselfde fout begaan as ek as vrygemaakte gereformeerde en daarom nou lid van die Geref. Kerk van Pretoria-Eloffsdal daardie kerk sou vereenselwig met een van die sinodaal Geref. Kerke in Nederland, wat ek reeds vanaf 1945 "vals" moes ag maar waarmee die Geref. Kerk in S.A. nog "enge" korrespondensie voer.

Ons sal die geskiedenis wat die opgestane Christus dikteer moet byhou en so ook dié stukkie kerkgeskiedenis waarvoor ek tans $u$ aandag vra.

\section{Schilder as confessor tot op sy dood}

Kan ek daarby ' $n$ beter getuie neem as die bybel- en belydenis-getroue prof. $K$. Schilder wat so baie nou by die Vrymaking betrokke was?

$\mathrm{Na}$ die sg. Vrymaking in 1944 het hy die vraag onder oë gesien: hoe moet vrygemaaktes handel as hulle na die buiteland trek om hulle daar blywend te vestig? 'n Antwoord op dié vraag was belangrik, omdat daar 'n baie hoog persentasie vrygemaaktes geemigreer het en omdat die buitelandse kerke swak geînformeer was oor die Vrymaking wat onder die Duitse besetting plaasgevind het.

Kernagtig het hy dit saamgevat in sy toeligting op artikel 29 N.G.B. (Christelike religie, 5e druk, bl. 99, vertaal):

„Ons moet erken dat God die historie gemaak het. In elke land het $\mathrm{Hy}$ 'n eie geskiedenis en 'n eie reformasie gewerk. Dit is nie normatief nie, maar ' $n$ feit waarmee ons by die toepassing van norme rekening moet hou. Wanneer 'n mens dan ook in 'n vreemde land kom, moet hy wel volhard in wat hy glo, natuurlik, maar hom daar ook aansluit by die kerk wat caput en fondamente (Maresius verwys na 1 Kor. $3: 11$ en Kol. 2 : 19 , L.G.) nie omkeer of wegwerp nie. As $\mathrm{gg}$. gebeur of 'n mens wil nie anders nie, dan is dit 'n valse kerk" (verwys na „De Refor- 
matie" van 14 Okt. 1932 , bl. 10 en van 21 Okt. 1932 , bl. 18). As ons na ons belydenis onderskei tussen „coetus" en ,congregatio", dan dui lg. op die Christus wat oor die hele wêreld sy "grex" (kudde) byeenbring (onvoltooide teenwoordige tyd!) en dit doen langs paaie wat ons soms verras. Maar $\mathrm{Hy}$ doen dit onafgebroke, soos Sondag XXI van die H.K. aandui. En óns co-ire sal daardie congregatio moet byhou. Ons belydenis (art. 27 N.G.B.) verbind die woorde coetus en congregatio nie verniet met die woordjie ,seu” (of), anders is die kerk geen „ware" kerk meer nie.

Van die „college-dictaat De Kerk" van prof. Schilder (4e druk) vertaal ons uit bl. 133:

"In die coetus-gedagte lê die element van die vrye samekoms.

In die congregatio-gedagte gaan dit om dieselfde onderwerp, maar dan word die aandag gevestig op die element van bo (die wil van die Herder) wat altyd in die kerk aanwesig is, die sg. verrassingselement. Hierdie element plaas ons voor God se vrye verkiesing, waarvolgens die Woord orals gesend word waar Hy dit wil. Ons kan die kerk in sy voortgang net maar goed sien, as hierdie element in rekening gebring word."

Daarby sluit baie mooi Schilder se XIe stelling insake die kerk aan, wat ons op bl. 145 lees:

„Omdat die wil om gelowiges uit alle plekke en gedurende alle tye te vergader die eerste merkteken van die kerk is (omdat daarin Christus se werk hom in ons mede-arbeid met Hom voltrek), is dit 'n prinsipiële fout van die allereerste orde as 'n mens "merktekens" van die kerk of „,indelings" van die kerk probeer te gee, waarvan die criteria of met hierdie criterium stry of daarvan geabstraheer is."

Juis in hierdie tyd waarin die horisontalisme ook in die kerk veld win en die platvloerse ,medemenslikheid" die God se beelddraer wees oorskadu is dit noodsaaklik om baie duidelik te stel, dat Christus se verrassende congregatio vooropgaan. Christus is nie ons medearbeider nie, maar ons moet Chrístus se mede-arbeiders wees.

As Maker van die geskiedenis het $H y$ sy kerk met die koms van Jan van Riebeeck in Suid-Afrika geplant (vergelyk Jan van Riebeeck se gebed) en omstreeks 1859 geformeer. 'n Eie Skrifgebonde Gereformeerde Kerk. Dit is ' $\mathrm{n}$ feit. Ooreenkomstig die Bybel is daar selfstandige plaaslike kerke, watter ampsdraers via die amp van alle gelowiges deur Christus aangestel is en aan Hom verantwoordelik bly. Daardie plaaslike kerke moet mekaar tot 'n hand en 'n voet wees. Binne elke nasie. So ontstaan 'n nasionale kerkverband van susterkerke. Want die Evangelie moet gebring word en is gebring aan die nasies (Matt. $28: 19$ ). In hierdie teks staan dit daar nog krasser: „maak dissipels van al die nasies”! Origens verwys ons na die talewonder op die Pinksterdag en ten slotte na Openbaring 5 : 9: "met u bloed gekoop uit elke stam en taal en volk en nasie" en na hoofstuk $7: 9$ : "uit alle nasies en stamme en volke en tale".

Tereg sê Schilder dat ons van hierdie historiese feite geen norme mag maak nie. Jy kán as kerklid of as plaaslike kerk tot 'n buitelandse kerkverband behoort. Dan sal die omstandighede dit ook reg. verdig. So was die Gereformeerde Kerke in Nederlands-Indië - 
in dié tyd 'n kolonie van Nederland - tot 1920 ,buitekerke" van die klassis 's Gravenhage en daarna het hulle tot 1947 as klassis Batavia tot die verband van die Gereformeerde Kerke in Nederland behoort. Maar die Hollanders wat daar gewerk het was geen immigrante nie; deurgaans het hulle op 50-jarige ouderdom afgetree en gerepatrieer.

Anders is dit ewewel wanneer jy 'n nuwe vaderland kies vir jou en jou kinders. Dan moet jy jou afvra, of die kerk in jou nuwe nasie caput en fondamente (sien bo) al dan nie omgekeer of weggewerp het nie. Eie kerkstigting is dan eers toelaatbaar en tewens vereis as daardie gemeenskap wat hom as kerk presenteer 'n valse kerk is én na die bring tot 'n wat Schilder noem "Entscheidung" weieragtig is om 'n kerk te word wat die merktekens van die ware kerk dra.

Die immigrant sal die Jode 'n Jood, die Grieke 'n Griek en die Afrikaner 'n Afrikaner moet word, natuurlik onder die beding van bo-genoemde „tensy". En hierdie „tensy” moet bewys word... langs die kerklike pad.

In hierdie geval wil ons opnuut Schilder siteer soos hy op 16 Julie 1949 in "De Reformatie" op bl. 350 geskryf het (ons vat daarvan met dié gedeeltes wat 'n algemene strekking dra):

„Vir ons emigrante:

En dan: afsonderlike instituering op die grondslag van die feit van die vroeëre lidmaatskap van 'n Nederlandse ,vrygemaakte' kerk? Ons glo dat ook daarvan niks kan kom nie. Primo, omdat 'n feit uit die verlede nooit grondslag vir kerkstigting is nie.

Quinto, omdat dit nie goed is om by die binnekoms in 'n seker land die geskiedenis wat dáár agter die rug lê te vergeet en net te doen asof daar nog nooit enigiets gebeur het op die gebied van kerkstigting en kerkverband nie. As daar reeds kerke is op die grondslag van die drie formuliere, dan is daar al gewerk deur God se Gees, en moet niemand Hom in sy werk ignoreer nie."

Om daarop te wys dat hierdie artikel nie net bedoel om emigrante na Kanada en die V.S.A. van advies te dien nie, maar ook hulle wat na Suid-Afrika getrek het of sou gaan emigreer, haal ons ook aan: ,wat wéét ons eintlik van Amerika en van Suid-Afrika?" Laat ons hierdie datum: 16 Julie 1949 goed vashou.

\section{Die vrygemaaktes in S.A. voor 1950}

Nou nader ons die datum van die stigting van die Vrye Gereformeerde Kerk te Pretoria, wat op 8 Oktober 1950 plaasgevind het, en die jaar 1951, waarin die gen. sinode van die Gereformeerde Kerke in Nederland (vrygemaak) besluit het om daardie kerk in Suid-Afrika as susterkerk te erken.

Een van die broeders wat by daardie stigting van die Vrye Geref. Kerk ouderling geword het, het voor sy emigrasie 'n brief aan prof. K. Schilder geskryf en hom om advies gevra hoe om kerklik te handel by sy aankoms in Suid-Afrika. Deur middel van sy sekretaris het Schilder hom laat weet: luister goed na die preke, handel 
na omstandighede en gebruik jou gesonde verstand en, wat die reformatoriese werk betref, soek en hou kontak met ander vrygemaakte emigrante. Tot sy diepe teleurstelling het Schilder nie vir hom gesê: stig 'n eie kerk nie.

Dieselfde vrygemaakte broeder het in hierdie lyn op 26 Julie 1949 - dus ruim 'n jaar voor die stigting van die V.G.K. te Pretoria - 'n belangrike stap vorentoe gedoen. Aan alle Gereformeerde leraars en professore in die teologie het hy - daartoe finansieel in staat gestel deur ' $n$ in Nederland opgerigte komitee tot verspreiding van Geref. lektuur - die juis van die hand van ds. C. Veenhof afkomstige boek „Om de ,Unica Catholica' " toegestuur met die dringende versoek om daarvan noukeurig kennis te neem en om die vraag in oënskou te neem: wie was na 1944 die wettige voortsetting van die Geref. Kerke in Nederland en wel i.v.m. die buitelandse korrespondensie. 'n Lofwaardige strewe.

Die direkte reaksie daarop was prakties niks nie. Maar dit is wel merkwaardig dat omtrent dieselfde tyd onder leiding van ds. P. G. W. Snyman 'n sg. „Schilderfonds" opgerig is met die doel om prof. K. Schilder in staat te stel om 'n besoek aan Suid-Afrika te bring, sodat hyself oor die Vrymaking voorligting sou kon gee.

Om op die versending van „Om de ,Unica Catholica' " terug te kom - en hierdie saak is van wesenlike belang in hierdie artikel -, in die begeleidende skrywe kon al die lerare en teologiese professore van die Gereformeerde Kerk in S.A. in die slot die volgende lees: „In hierdie land is daar 'n aantal Gereformeerdes (die meeste van hulle Nederlandse immigrante, maar ook Gereformeerdes van Afrikaanse nasionaliteit) by wie daar 'n sterk begeerte leef, om tot klaarheid te kom oor hierdie saak. Hulle wens die eenheid tussen die Geref. Kerk in Suid-Afrika en in Nederland weer terug soos dit van ouds bestaan het, en hulle wil tot die eenheid kom deur hulle te rig, via die plaaslike kerkrade, tot $u$ meerdere vergaderings. Hulle wil hierdie vergaderings vra om herstel van die korrespondensie met die wettige Geref. Kerke in Nederland (onderhoudende art. 31 K.O.)."

Die Gereformeerde Kerk in S.A. - altans hul lerare - het so baie goed kon weet wat daar van die vrygemaaktes se kant sou kom. Dit sal hulle ook aangespreek het, want dit was Gereformeerde kerkstyl. Uit hul midde sou die saak van die finale keuse van die toekomstige Nederlandse korresponderende kerk gestel word en as die fondse toereikend sou wees, was die kans groot dat prof. Schilder self die verlangde voorligting sou gee. Tot sover het dit regtig goed gegaan.

\section{Die Gereformeerdes in S.A. voor 1950}

Vergeet ons nou nie die skriftelike kontak tussen die Gereformeerde Kerk in Suid-Afrika en die Gereformeerde Kerke in Nederland (vir die pos aangedui as onderhoudende art. 31 K.O.), wat van vroeër datum is as midde 1949 ?

Ons moet daarby onderskei tussen die direkte en die indirekte korrespondensie. 
Met lg. bedoel ons die korrespondensie wat handel oor die Geref. Ekumeniese Sinodes, waarvan die eerste in 1946 te Grand Rapids plaasgevind het.

Dit is 'n bekende feit, dat die Geref. Kerke (vrygemaak) op goeie Skriftuurlike en konfessionele gronde in 1948 die uitnodiging om aan die tweede G.E.S. - nl. die te Amsterdam - deel te neem afgewys het. Hierdie besluit het ewewel eers op die Geref. Kerk in S.A. se sinodetafel gekom in 1952 en val om die rede buite die raamwerk van hierdie artikel. Dit het ewemin behoort tot wat - soos nog op bl. 9 sal blyk - ds. F. A. den Boeft met die Geref. deputate vir buitelandse korrespondensie sou bespreek en het bespreek.

In ' $n$ ander verband hoop ons ewewel daarop terug te kom. Tans die direkte korrespondensie tussen die Geref. Kerke in S.A. en die Geref. Kerke in Nederland (vrygemaak). Oor hierdie saak kan ons baie kort wees. Ons lees daaroor in die Handelinge van die sinode van 1955 en wel op bl. 38:

„Die deputaatskap vir Korrespondensie van ons Generale Sinode het in April 1946 ' $n$ skrywe ontvang van De Gereformeerde Kerken (onderhoudende Art. 31) met 'n uitnodiging om 'n afgevaardigde te stuur na hul sinode wat in 1946 gehou sou word. Die Deputaatskap het geantwoord dat ons Sinode net verby is en dat die brief van De Geref. Kerken (onderhoudende Art. 31) op die ev. Sinode voorgelê sal word. Daardie Sinode (Jan. 1949) het die saak behandel en besluit: (die stuur van 'n afgevaardigde), kon natuurlik nie; en nou word aanbeveel dat, aangesien ons in korrespondensie staan met De Geref. Kerken in Nederland, en die toestand daar nog wisselvallig is, ons 'n afwagtende houding inneem. Intussen hoop en vertrou ons dat die breuk daar deur Gods genade herstel mag word (Akta 1949 , bl. 290 (10))'. Van hierdie besluit het die deputate vir korrespondensie 'n afskrif gestuur aan De Geref. Kerken (onderhoudende Art. 31). Hierop is geen offisiële antwoord ontvang nie" (tot op Jan. 1955, L.G.).

Net 'n kort vraag: hoe kan 'n mens by 'n saak in dispuut „'n afwagtende houding inneem", terwyl hy sy keusebepaling gedoen het en die band aan die gekose party as argument gebruik om die ander party af te wys? En as kort kommentaar: die gedagte aan dubbele korrespondensie het toe nog nie posgevat nie. Maar die Gereformeerdes in S.A. kon weet, dat hul korrespondensie met die sinodaal Geref. Kerke in Nederland vir die Geref. Kerke in Nederland (vrygemaak) dié groot struikelblok was. As iemand vir ruimer korrespondensie bedank, soveel te sterker sal hy dit doen vir enger korrespondensie. So wisselvallig was die kerklike toestand in Nederland nie.

\section{Agt Oktober 1950}

Tans kom ons by die skarnier waarom hierdie artikel draai. Ons mag en moet wel van 'n skarnier praat, want die stigting van die Vrye Geref. Kerk te Pretoria as daad was die oprigting van 'n teenkerk: 'n publieke getuienis in die Suid-Afrikaanse kerklike wêreld. Die vraag is net: watter getuienis het daarvan uitgegaan? As 
ons Jesus se Hoëpriesterlike gebed ernstig neem - en vir Gereformeerdes is dit 'n noodsaak - beteken die stigting van 'n "teenkerk" dat die in Suid-Afrika aanwesige kerke geen kerke is nie of altans geen ware, wettige kerke is nie. Die bewyslas het daarby gerus op dié Gereformeerdes wat na Suid-Afrika geëmigreer was, seker in hierdie geval dat daar 'n Geref. Kerk was wat presies dieselfde belydenisformuliere had as die binnegekome immigrante.

Vanuit Indonesië het ds. F. A. den Boeft, wat toe nog 'n leraar was van die Ned. Geref. Kerke (vrygemaak), op sy repatriasiereis na Nederland op versoek van 'n paar vrygemaaktes hier en met toestemming van sy Ned. kerkraad 'n draai na Suid-Afrika gemaak, drie jaar na die geregverdigde herstigting van die Geref. Kerk in Batavia, waaraan hyself geen deel gehad het nie. Daardie worsteling met broeders van dieselfde huis om tot 'n verantwoorde beslissing te kom, was vir hom vreemd. By sy aankoms in Ned. Indië was daar reeds 'n gekonsolideerde situasie: drie kerke met 'n groot aantal lede.

Om rede van die feit dat die skrywer van hierdie artikel na 1955 baie persoonlike kontakte met ds. Den Boeft gehad het, mag ek terloops wel opmerk, dat lg. deur sekere omstandighede buite sy wil in sy eie vrymaking daardie worsteling ook nie geken het nie.

So kan ek my maklik voorstel dat ds. Den Boeft vir homself die situasie in Suid-Afrika identiek gestel het met die in Ned. Indië, wat inmiddels Indonesië geword het. Dáár was in 1950 selfstandige Geref. Kerke wat korrespondensie met die Sin. Geref. Kerke in Nederland voer; hier ook. Dáár was (vrygemaakte) Geref. Kerke gestig; dit moes hier ook gebeur. As ons bowendien nog in rekening bring dat in sy lewe ,das Gebot der Stunde" 'n belangrike plek ingeneem het en die woorde "dadelijke gehoorzaamheid" - dadelik met betrekking tot die tyd - vir hom 'n gebiedende eis was, dan kan ek suiwer op die menslike vlak verstaan, dat hy in Suid-Afrika gehandel het soos hy gehandel het, en wel as adviseur van 'n klein aantal vrygemaakte immigrante in en buite Pretoria en twee susters van Suid-Afrikaanse nasionaliteit én tegelyk as voorsitter van die Ned. deputaatskap vir korrespondensie met buitelandse kerke.

Dog met alle persoonlike begrip vir hierdie instelling en aanpak, moet ons nou reeds sê, dat sy siening heeltemal anders was as die van prof. K. Schilder, watter laaste siening as nou by die Heilige Skrif aansluitende in die Ned. Gereformeerde Kerke (vrygemaak) prakties algemeen aanvaar was.

Soos Schilder die geskiedenis, waarin ook God se hand is, in al sy beslissings in rekening bring en tot op sy afsterwe in rekening gebring het, was daar by Den Boeft 'n sekere verwaarlosing van daardie God se diktaat.

Ons sien dit onmiddellik raak in die verslag van sy bespreking met die Gereformeerde deputate vir buitelandse korrespondensie op 30 Augustus 1950 . Ons kan daarvan kennis neem deur die sinodale Handelinge 1952 op bl. 155 en 153 op te slaan en te lees (Deputateverslag plus Verklaring). Aanleiding tot daardie bespreking was 'n brief wat op versoek van hierdie deputate op 15 Augustus 1950 geproduseer is en wat soos volg lui: 
Aan den scriba van het College van Deputaten voor

(Sonder datum).

Correspondentie met de Buitenlandsche Kerken.

Geachte Collega,

$\mathrm{Nu}$ ik hier in Zuid-Afrika vertoef heb ik een opdracht gekregen om als voorzitter van het College van Deputaten voor Correspondentie met de Buitenlandsche kerken met uw geacht College contact te zoeken om de nog steeds niet opgeloste kwestie van correspondentie tusschen de Gereformeerde Kerken in Holland en uw kerk onder oogen te zien.

Deze kwestie is in de Gereformeerde Kerk aan de orde geweest op de Synode van Enschede en toen is er even een briefwisseling over deze materie geweest, een briefwisseling, die evenwel nog nooit tot een definitief besluit heeft geleid.

Ds. Spoelstra noemde mij uw naam als scriba van Deputaten en daarom richt ik mij met dit schrijven tot $u$ met het verzoek of het $u$ mogelijk zal wezen een vergadering van uw college van Deputaten samen te roepen, opdat we met elkander deze materie mondeling kunnen bespreken.

Het ligt in mijn voornemen tot eind October in Zuid-Afrika te blijven en ik zou het zeer op prijs stellen om in verband met andere werkzaamheden spoedig, zoo het $u$ mogelijk is mij te doen weten tijd en plaats van uwe vergadering, waarnaar ik me graag zal schikken zooveel als in mijn vermogen is.

Hopende dat $\mathrm{u}$ aan mijn verzoek zult kunnen voldoen, verblyf $\mathrm{ik}$, Hoogachtend, uw dw.,

(W.g. F. A. den Boeft).

Afz.: Ds. F. A. den Boeft,

P.a. Dames Van de Mark,

De Kockstraat 393, Pretoria.

$\mathrm{Na}$ hierdie bespreking is die volgende verklaring gepubliseer, o.a. in „Die Kerkblad":

\section{VERKLARING}

insake onderhoud tussen die Deputaatskap vir Korrespondensie Geref. Kerk in Suid-Afrika en ds. F. A. den Boeft.

(Ons siteer net die gedeeltes wat vir hierdie artikel van belang is.) „Aan ds. Den Boeft is ruim geleentheid gegee om sy saak te stel en verskillende vrae is tot hom gerig. Uit die bespreking het die volgende sake gekristalliseer:

1. Ds. Den Boeft beskou sy kerk as die wettige voortsetting van die "Geref. Kerken in Nederland" met wie die Geref. Kerk in S.A. nog altyd korrespondensie onderhou het.

2. Ds. Den Boeft het beswaar dat prof. Berkouwer op ons Sinode van 1949 teenwordig was en geen verteenwoordiger van sy kerk nie. Ook het hy beswaar dat prof. Berkouwer hier gepreek het, terwyl ons kansels, volgens sy verklaring, vir hom gesluit is.

3. Gevra waarom hy tot die konklusie gekom het dat hy as prediker vir die Geref. Kerk in S.A. nie aanvaarbaar is nie, 
het ds. Den Boeft geantwoord dat hy, soos sake nou staan, geen uitnodiging sou aanneem om vir een van ons Gereformeerde gemeentes te preek nie. Die saak van korrespondensie, het hy verklaar, moet eers gereël word.

4. Met die oog op die feit dat prof. Berkouwer wel in die Geref. gemeente mag preek en hy nie, het ds. Den Boeft beswaar dat lidmate van sy kerk hulle voeg by die Geref. Kerk in S.A. Dit sou onreg wees teenoor hulle predikante wat in Nederland afgesit is. Waar hy as dienaar van die Woord nie aanvaarbaar is nie, is hulle ook nie as lidmate aanvaarbaar nie.

5. Gevra of hy van plan is om in S.A. 'n kerk te institueer, het ds. Den Boeft geantwoord dat lidmate van sy kerk nie sonder bediening van Woord en sakramente kan bly tot 1952 wanneer die Sinode van die Geref. Kerk in S.A. oor die saak van korrespondensie sal beslis nie. Ds. Den Boeft sal dus 'n eie kerkverband hier institueer, en ná die Sinode van 1952 sal die hele situasie in heroorweging geneem word."

Dan volg in daardie verklaring die konklusie van die Deputate dat hulle niks anders kon as wat die Sinode in 1949 besluit het nie (sien ons kommentaar daarop op bl. 41) met beklemtoning van die woorde: „Intussen hoop en vertrou ons dat die breuk deur Gods genade herstel mag word" en kom die uitermate belangrike sinne: „Niks is verder van ds. Den Boeft verneem nie, ook nie wat sy verdere optrede betref nie. Uit Nederlandse blaaie wil dit voorkom of 'n gemeente gestig is."

Wat kon die Sinode in 1952 anders doen as om te besluit:

„Die eerw. Sinode besluit om die saak van ons verhouding tot bogenoemde kerke op te dra aan 'n deputaatskap, veral ook na aanleiding van die optrede van ds. Den Boeft in ons land en aan die volgende sinode te rapporteer" (bl. 163 Handelinge)? Mag ons hierop 'n kort kommentaar lewer en dit in die lyn van die Skriftuurlike gedagtes wat in die jare na die Vrymaking in ons midde gemeengoed was?

a. Die persoonlike kontakopname met die Geref. Kerk in S.A. in 1950 het 'n improvisoriese karakter gedra wat nie in verhouding gestaan het tot die belang (Joh. 17) wat daarby gemoei was nie. In die Nederlandse vrygemaakte Geref. Kerke (as meeste vergadering staan die sinode en hul deputaatskappe onder die plaaslike kerkrade) was daar geen voorbereiding vir daardie ontmoeting op 30 Augustus 1950 nie.

b. Ds. Den Boeft het buite sy boekie gegaan, toe hy, pratend oor die saak van buitelandse korrespondensie, daaraan onmiddellik die stigting van 'n eie kerkverband gekoppel het en verklaar het nie te kan wag op die Geref. Sinode in 1952 wat in teenstelling met die deputaatskap vir buitelandse korrespondensie daardie korrespondensie wél kon en mog behandel nie. Waar hierdie Dopperdeputate na Geref. kerkreg nie mog handel nie, mog hy as voorsitter van die Nederlandse deputaatskap vir buitelandse korrespondensie nie oorgaan tot adviesverlening aan 
'n paar vrygemaakte gesinne om tot onmiddellike kerkinstituering te kom nie (laasgenoemde daad is baie ingrypender as eersgenoemde). So skeur jy die kerk wat een moet wees sonder jou medebroeders in Suid-Afrika die kerkregtelike gebode tydruimte te gee om tot ' $n$ verantwoorde besinning te kom. Jou private tempo om kerklik te handel mag jy nie bindend aan ander oplê nie, seker nie as die ander in sy onmag om adekwaat te reageer hom op jou eie kerkreg beroep nie. Anders tree jy ultimatief op, soos ons so baie kere van die Sinodale se kant smartlik ondervind het. Vanuit Nederland was daar geen opdrag tot kerkstigting nie. Daartoe het hy op eie houtjie geadviseer.

c. Is die gedagtegang van ds. Den Boeft dan nie sluitend nie? Glad nie. Hy het net in die horisontale vlak geredeneer en sowel die Skrif (Joh. 17) as die Konfessie (art. 27-30 N.G.B. en Sondag XXI van die H.K.) geïgnoreer. Voordat hy van die een onderwerp: buitelandse korrespondensie, wat inderdaad foutief geadresseer was maar waarby ons ook vir die Suid-Afrikaners in rekening moet bring hul onkunde oor kerklike sake in Nederland (,De Reformatie" van 16 Julie 1949), ongeoorloof (sien b) oorgestap het na die onderwerp: stigting van die kerk - vir die Doppers 'n teenkerk -, het hy nòg na die Bybel nòg na sy belydenis gegryp om - soos Schilder - te vra: Is die Geref. Kerk in S.A. vals of met 'n ernstige gebrek in sy buitelandse korrespondensie, waar? Het daardie kerk na 'n „Entscheidung” caput en fondamente omgekeer of weggewerp en wil hy nie anders nie (sien bl. 37) of word daar bereidheid gevind om met mekaar broederlik te praat oor wat teen God se wil skeiding teweeg gebring het?

d. In die Dopperdeputate se verslag word geen melding gemaak van die „Om die ,Una Sancta" se begeleidende brief wat alle predikante en professore ontvang het (sien bl. 40) nie, maar daardie Geref. siening oor die bewandeling van die kerklike weg wat die „vrygemaaktes" self belowe het om te doen, is in daardie verslag verwerk. Bowendien het ds. T. T. Spoelstra wat voor 30 Augustus 1950 'n noue persoonlike kontak met ds. F. A. den Boeft gehad het, 'n warm beroep op lg. gedoen om daardie pad: kerkraad, klassis en sinode desnoods as gaslid sy mede-vrygemaaktes in Suid-Afrika aan te beveel. Maar daardie brief van 26 Julie 1949 het by die stigting van die Vrye Geref. Kerk te Pretoria glad nie meer ter sprake gekom nie! Daar was op die sinode in 1952 dan ook geen enkele blyk van S.A. vrygemaakte kant om ter sake van die korrespondensie tot 'n „Entscheidung" te kom nie, terwyl daar van Dopperdeputate se kant tog gesê is (sien punt 5 van die Verklaring hierbo): dán sal ons daaroor beslis.

e. Volgens bogenoemde verslag - en dit word deur getuienis bevestig - sou die instituering van die Vrye Geref. Kerk te Pretoria 'n tot 1952 voorlopige karakter dra. O.i. is dit 'n kerkregtelike en Skriftuurlik ongeoorloofde daad, met 'n ernstige gevaar, nl. dat hierdie "voorlopig" „permanent" gaan word. Om dié rede het na die oorlog die Geref. Kerke (vrygemaak) 
die instituut van ,noodgemeente" wat in Ned. Indië gerealiseer is radikaal verwerp. Dit was vir ds. Den Boeft baie goed bekend. Ons gaan daarop nie verder in nie, maar moet wel opmerk dat daardie „voorlopigheid" tans reeds amper 25 jaar - 'n generasieouderdom - voortduur. Aan daardie gevaar het die vrygemaaktes dus nie ontsnap nie. En die kontinuasie is vir 'n goeie deel hul eie skuld. Want - ons het dit reeds gesê - in 1952 het daar van ds. Den Boeft of die Ned. deputate vir buitelandse kerke se kant nog geen enkel reaksie ter sinode-tafel binnegekom op die gesprek van 30 Augustus 1950. En watter geleentheid was daar nie! Die aan ds. Den Boeft medegedeelde besluit van $1949-$ op bl. 41 gekommentariseer - was so aanvegbaar soos dit maar kan. Die voorlopige karakter van die instituering van die Vrye Geref. Kerk te Pretoria is ten slotte - en ons moet dit ook meld - nog voor 1952 tersyde gestel deur die kerkraad van daardie kerk blykens 'n brief wat gerig was aan die sinode van 1951 van die Ned. Geref. Kerke (vrygemaak) en bedoel het om erkenning te kry as korresponderende kerk en waaruit ons slegs hierdie gedeelte siteer (Acta Kamper Gen. Sinode 1951, bl. 93):

„Na verbreking van de gemeenschap met hen, die door hun kerkelijke handelingen bewijzen gemeenschap te zoeken en te onderhouden met de ontrouwe, gebonden kerken in Nederland, is De (Vrye) Gereformeerde Kerk van Pretoria geinstitueerd."

Moet ons ons verbaas oor die feit, dat daardie Ned. Sinode tot die besluit gekom het om die Vrye Geref. Kerk van Pretoria as susterkerk - in die enger sin van die woord - te erken? As dié sitaat ooreenkomstig die waarheid was, sou ons ondanks die gebrek van 'n te grote haas: dit was mos nog geen 1952 nie?, kan sê: Nee. In daardie lig moet ons ook sien wat Schilder in die jaaroorsig (Handboek 1951) skryf oor die instituering van die V.G.K. te Pretoria ... en dit billik. Maar dit is nie die waarheid nie. Daar was nòg gemeenskap met die sg. Dopperkerk nòg 'n verbreking nie. In hierdie sitaat lees ons twee keer die woord "gemeenskap". Dit moet in hierdie verband beteken: kerklike gemeenskap. So 'n gemeenskap was daar nie! In daardie tyd het die Vrye Geref. Kerk net bestaan uit 4 gesinne en 2 ounooiens. Lg. van Suid-Afrikaanse nasionaliteit was reeds voor die instituering geen lidmate meer van die Geref. Kerk in S.A. nie. Die twee ouderlinge was nooit lid van enige Geref. Kerk, altans nie in Suid-Afrika nie. Moontlik wél die enigste diaken. Om dán te spreek van 'n „gemeenschap" is net leuenagtig. Geen van die twee ouderlinge het voor die stigting van die Vrye Geref. Kerk aan die nagmaalstafel as tafel van gemeenskap in die Geref. Kerk deelgeneem nie.

Vervolgens die „verbreking". Eerstens, as daar geen gemeenskap - moontlik op een uitsondering na - was nie, kon daar ook geen verbreking van die gemeenskap plaasvind nie. Tweedens moes ook die woord „verbreking" kerklik opgevat wees, altans vir die broederskap in Nederland. Jy skryf as kerkraad nie aan 'n sinode - 'n kerklike vergadering - oor „verbreking" nie 
sonder dat jy bedoel ,'n kerklike verbreking", 'n verbreking langs die kerklike weg, waarvan die bewandeling teenoor Suid-Afrikaanse lerare en professore toegesê was blykens reeds genoemde brief wat in samewerking met 'n Nederlandse komitee tot stand gekom het. So ' $n$ verbreking was daar nie. Dit was nog geen Januarie 1952 - die datum waarop 'n eventuele verbreking eers kón plaasvind - nie. Maar dit is ook 'n feit, dat geen van die in Suid-Afrika aanwesige vrygemaaktes die appẻlweg wat begin by die kerkraad en eindig by die "meeste" vergadering bewandel het nie. Hierdie aan die Nederlandse Sinode gepresenteerde argumentatie van die stigting van 'n teenkerk kan ons nie anders kwalifiseer as grootpraat, wat nie met die waarheid ooreenstem nie. So het die Satan as skeidingmaker sy kans gekry. 'n Paar mense wat nie eerlik was nie.

\section{Die gevolge van die V.G.K. te Pretoria se stigting}

Ons het feitlik maar min lus om verder te skrywe. Nie om genoemde paar mense se ontwil nie. Hulle sal die stigting van die Vrye Geref. Kerk te Pretoria nie meer voor hulle rekening neem nie. En ons sal vergewingsgesind moet wees. Maar vanweë die resultate wat die groot Teëstander van God daardeur en daarna bereik het sowel in die Vrye Geref. Kerk in S.A. as in die Geref. Kerk in S.A., as ook in die Ned. Geref. Kerke (vrygemaak).

a. Om met die laaste te begin, in die Acta Gen. Synode Bunschoten in 1958, op bl. 170 lees ons:

Wêl korrespondensie ,met Die (Vrye) Gereformeerde Kerke in S.A., tengevolge waarvan een correspondentie met Die Gereformeerde Kerk niet kan worden aangegaan, zolang in Zuid-Afrika de afzondering van Die (Vrye) Gereformeerde Kerke bestendigd blijft."

Van voorlopig na finaal - amper ongemerk - en van finaal na 'n sleutelposisie in die hereniging van twee susterkerkverbande van dieselfde konfessie. En dit ... terwyl juis in daardie tyd die Vrye Geref. se kerkverband uitgebrei word met 'n kerk (Kemptonpark) wat ten onregte die Geref. Kerk in S.A. as geheel in 'n Akte van Afskeiding en Weerkeer as vals kwalifiseer. Die Vrye Geref. Kerke se erkenning van die onregmatigheid daarvan dateer eers van 18 Des. 1972 !

Is daar in Nederland nog in rekening gebring die sinode-besluit van 1936 waarin as eis vir korrespondensie met buitelandse kerke gestel is: „Regelmatig onderzoek inzake trouw aan belijdenis en kerkregering"? Is die reëlmaat - sou ons kan vra - daar net om die 20 jaar? Want hierdie Dopperkerk-valsverklaring deur die Vrye Geref. se kerkverband-daad het amper 15 jaar geduur. Hoe kan dit die samesprekingsfeer bevorder? Onwaarheid is altyd gif wat deurvreet.

b. Ook die Geref. Kerk in S.A. het deur bogenoemde skismatiek skade gely. Hoe kan jy anders verklaar die bl. 78/79 in die Sinodehandelinge van 1958, waar die konfessionele onderskeiding ware en valse kerk tot 'n karikatuur omgeskape word en as 'n pleitgrond kan diens doen vir vals-ekumeniese aksies? Slegs 'n vroeëre Chris- 
telike Gereformeerde het as sinodelid in 1958 offisieel protes daarteen laat aanteken. Vandag sou dit anders gaan.

c. Die skade in die Vrye Geref. Kerke, hoe klein hulle lidmateaantal ook mag wees, moet wel die grootste geag word. Die vrygemaaktes moes deur hulle deelname aan die reformasie in 1943/1944 in Nederland 'n getuienis wees vir die Geref. Kerke in Suid-Afrika wat - soos dikwels gekonstateer is - in 'n situasie verkeer as van „De Gereformeerde Kerken in Nederland” in die jare voor die Vrymaking; 'n getuienis in leer en lewe. Maar ag, dit is jammer om te sê, hierdie "getuienis" het net die teenoorgestelde bewerk. Terwyl die reformatoriese werke van Schilder, Greijdanus en Holwerda gekoop en gelees word, vrugte afwerp en so aanleiding gee tot blydskap by kinders van God in die Geref. Kerk en daarbuite, was daar altyd maar weer droefheid van die een jaar op die ander oor wat 'n aantal kinders van die Vrymaking in hul konfessioneel en kerkregtelik onverdedigbaar isolement gedoen en nagelaat het. Sonder spesifiek op daardie afwykings van Skrif, belydenis en kerkeordening in te gaan, was daar by ouderlinge bevoegdheidsoorskryding, by predikante val in growwe sonde en prediking van 'n van die Skrif afwykende leer, by kerkrade telkens opnuut en tot vandag toe 'n kerkregtoepassing wat met die basiese reëls van die Dordtse kerkeordening in stryd kom en by kerklede in die algemeen 'n hulleself beter ag as die ander.

As jy dié sake noukeurig ondersoek, moet die konklusie wel lui: alles vind sy oorsaak in die voor die Here se aangesig nie-verantwoorde instituering van die Vrye Geref. Kerk van Pretoria. Hulle moes hulself teen die waarheid en werkelikheid in "waar" maak. Krampagtig. Maar jy kan nie teen God se ordinansie ongestraf stry nie. Art. 28 van die Nederlandse Geloofsbelydenis eindig met die woorde: „Daarom handel almal wat hulle van die ware kerk afskei of daarby nie aansluit nie, teen die ordinansie van God".

In al die 25 jare is daar nooit aangetoon dat die Geref. Kerk in S.A. vals is nie. En die een poging daartoe met 'n ruim dertienjarige nasleep het gefaal, soos dit gelukkig in 1972 gekonstateer is. Dit was soos die sinodebesluit lui 'n sonde teen die $9 \mathrm{e}$ gebod van die Here. Die wins ewewel uit daardie misstap is vandag nog nie sigbaar nie. Nog word deur ampsdraers in die Vrye Geref. Kerk te Pretoria die woorde „ware kerk” binne eie gemeenskap gehanteer vir die Vrye Geref. Kerk om Gereformeerdes wat na 24/25 jaar erns wil gaan maak met die slotwoorde van art. 28 N.G.B. te weerhou om die "heilloze pad" na die Geref. Kerk in S.A. - "een dal met dorre doodsbeenderen" (Es. $37: 4$ ) — in te slaan. Hierdie gesiteerde terminologie is perdfris.

'n Mens vra hom dan wel af, wat dan die bedoeling was van die woorde: „nie-vals" wat tydens 'n samespreking tussen deputate vir binnelandse kerke van die Geref. Kerk in S.A. en die Vrye Geref. Kerke in S.A. op 31 Julie 1972 deur laasgenoemde deputate teenoor eersgenoemde geuiter is as kwalifikasie van die sg. Dopperkerk?

In hierdie opstel wil ons geen verwyte maak nie. As iemand immers in woorde nie struikel nie (Jak. 3), is hy 'n volmaakte man 
en geen van ons is volmaak nie. Wel word hierdie feite, wat beslis nie alleen staan nie, gestel om aan te toon waartoe die 25-jarige waarmaking gelei het, nl. tot dubbeltongigheid en so tot 'n in-derdaad hantering van die deur die Heilige Skrif verworpe leer van die pluriformiteit van die kerk. Die verwerping van daardie valse leer is een van die sake waarvan ons kan sê, dat die vrygemaaktes daarin weergekeer het na Skrif en belydenis. Hierdie leer van Kuyper en later van Berkouwer mag en moet bestry word om in die lig van God se Woord die ware ekumene teenoor die valse te stel. Die oorsprong daarvan lê in die pragmatisme. Die ervaring van die feite en nie die geloof is daarby die ,leidsman". So is dit van vrygemaakte Gereformeerde kant by herhaling gestel.

Maar jou getuienis word volslae kragteloos, wanneer jy in jou dade self daardie on-Skriftuurlike praktyk beoefen, en seker daarin 25 jaar volhard. In die vrygemaakte kerke in Nederland sou dit met inagneming van dié tydsduur tereg as verloëning van die Vrymaking aangemerk word. Hier in Suid-Afrika is daar Geref. kerkrade wat van oordeel is: $u$ as Vrye Geref. Kerke het vanaf 1950 geen bestaansreg nie, die begin was onkerkregtelik en uit die vervolg blyk telkens opnuut dat $u \mathrm{u}$ vrygemaak het van die Dordtse kerkeordening en altans een van die merktekens van die ware kerk mis. Ander sê: die Vrye Geref. Kerklede verkeer wel 'n bietjie in verleentheid teenoor hul broeders uit die Vrymaking wat by ons aangesluit het: eenkant ecclesia semper schismatanda met: daar is maar een ware kerk as leuse in die vaandel waaronder hulle met mekaar stry, anderkant verwerp hulle ons nie as valse kerk nie en beoefen hulle so die pragmatisme van Kuyper se pluriformiteitskonstruksie; dié konstruksie is blykbaar tog nie só on-Skriftuurlik nie.

Die jongste uiting van die Vrye Gereformeerde Kerk se kant maak hierdie saak nie beter nie. "Nie vals" sou nog nie beteken „waar" nie. So kom die uitgeworpe pluriformiteitsleer weer deur die agterdeur binne. Sonder meer is nl. duidelik, dat dit heeltemal in stryd is met art. 28 N.G.B. en ook met die slot van art. 29 stry, wat lui: „Hierdie twee kerke (die ware en die valse) kan maklik geken en van mekaar onderskei word".

\section{Voortsetting òf weerkeer ?}

'n Mens peins partykeer: hoekom bly daar nog steeds 'n deel van die ,vrygemaaktes" kerklik apart staan teen hulle eie belydenis in. Jy sou dink: dit is die groot struikelblok van die nog steeds bestaande korrespondensie met die (valse) sinodaal Gereformeerde Kerk in Nederland. Natuurlik speel dit 'n rol, vir sommige selfs 'n oorwegende rol. Maar daar is reeds 'n aksentverskuiwing gaande. As in 1976 daardie band finaal en formeel verbreek sou word en dit word verwag en daarvoor word ook gebid -, sal daar ander swarighede sterker beklemtoon word, wat as argumente sal fungeer om tog nie een te word nie. Eie sonde en gebreke word daarby geignoreer; die by Doppers opgeblaas, tot in die absurde toe. Schilder se Skriftuurlike siening daaroor - orals om te vind in boeke en diktate wat verkoop word in N.G. Kerk-boekhandels - 
spreek hulle glad nie meer aan nie. My persoonlike ervaring op hierdie punt is waarlik skrikaanjaend. Dié wat deur hul ouderdom kennis dra van die situasie in de Ned. Gereformeerde Kerke voor die Vrymaking - waar, dog met baie gebreke en origens met ongeorganiseerde ,weerkeer"-aktiwiteite - moet met smart ervaar, dat die ,gebreke" van die sg. Dopperkerk vanaf 'n veilige afstand as selfgekonstrueerde, maar nimmer offisieel gestelde merktekens van 'n valse kerk en so as redes vir 'n kerklik moet geskeide bly onder mekaar deurvertel word en daar origens 'n liefdevolle steunverlening aan genoemde ,weerkeer" ontbreek, sodat dit lyk asof daardie groep vrygemaaktes van oordeel is dat die Geref. Kerke in Nederland voor 1942 reeds vals was. So lyk dit meer aannemelik dat die nasionalitseit ' $n$ belangrike rol speel, nl. een op die agtergrond. Hoe dikwels het ons nie hoor praat van die Hollandse immigrantekerk en hoe min weerspreek die Vrye Geref. Kerk se dade en nalatighede daardie kwalifikasie!

Mag dit ' $n$ vermoede wees, 'n feit is, dat, sodra daar toegegee word dat die Vrye Geref. Kerk te Pretoria in 1950 ten onregte gestig is, daar aangevoer word dat hierdie kerk daar nou eenmaal is en dat God by magte is om iets goeds uit iets sondigs te doen gebore word. My reaksie op daardie bewering was soos volg: „Het werpen van Joseph in de put en zijn verkoop aan Egyptenaren was een ernstige zonde, maar er kwam iets goeds uit voort (Gen. $45: 5$ ), doch zijn broeders hadden tot tweemaal toe diep berouw over die wandaad (Gen. 42 : 21 en 50 : 15-17)".

Ek sou net wil vra: wanneer kom die berou oor die sondes van 1950? Daar was die afgelope 25 jaar baie meer en ernstiger ellendes as hongersnood en gevangenskap. Kerklike ellende as die gevolg van die skismatiek in die begin.

Die Romeinse juriste ken die reël: "Quod ab initio nullum est non potest tractu temporis convalescere" (wat vanaf die begin nietig is kan nie deur verloop van tyd regsgeldig word nie), maar die gelowige sê: die gesondmaking kan kom, nie deur verloop van tyd nie, maar deur erkenning van die siekwees, want die Groot Geneesheer staan dan klaar om te heel. Daarvoor het hy 1975 jare gelede sy bloed gegee.

Geen Voortsetting nie - die van 1969 was ook sondig -, maar opregte Weerkeer tot die „Una Sancta” en wel voor Januarie 1976.

Dan mag ons Josef en sy broers navolg: trane van blydskap! Is ons geen kinders van dieselfde Vader nie? 